DOI 10.37882/2223-2974.2020.12.37

\title{
ПРОЦЕССУАЛЬНЫЙ ПОРЯДОК ИЗБРАНИЯ МЕР ПРЕСЕЧЕНИЯ
}

\section{PROCEDURAL PROCEDURE FOR CHOOSING PREVENTIVE MEASURES}

V. Firsov

Summary: The article discusses the procedure for choosing preventive measures in Russian criminal proceedings, at the same time, attention is drawn to the need for sufficient grounds for choosing a preventive measure. In addition, the exclusivity of the choice of preventive measures in relation to the suspect is considered. The article analyzes the decision on the choice of a preventive measure as a legal form of obtaining new knowledge and the basis for the formation and implementation of both new legal relations, and the development or acquisition of new qualities by existing legal relationships.

Keywords: a preventive measure, house arrest, basis, sufficient population, decree, election and application.

\author{
Фирсов Владимир Григорьевич \\ Независимый исследователь \\ firsov_vg65@mail.ru
}

Аннотация: В статье рассмотрен порядок избрания мер пресечения в российском уголовном судопроизводстве, при этом обращено внимание на необходимость достаточности оснований для избрания меры пресечения. Кроме того, рассмотрена исключительность избрания мер пресечения в отношении подозреваемого. В статье анализируется постановление 06 избрании меры пресечения как правовая форма получения нового знания и основания формирования и реализация как новых правовых отношений, так и развития или приобретения новых качеств уже имеющимися правоотношениями.

Ключевые слова: мера пресечения; основания; достаточная совокупность, исключительность, постановление, избрание и применение.

конституционных принципов, касающихся прав и свобод человека и гражданина [1].

Цели мер пресечения взаимосвязаны с назначением уголовного судопроизводства, без мер процессуального принуждения невозможно осуществление функций уголовного преследования, разрешения уголовного дела, а также гражданско-правовой функции.

Признание, соблюдение и защита прав и свобод человека и гражданина - обязанность государства (ст. 2 Конституции РФ). Вместе с тем, применение любой меры процессуального принуждения обязывает субъекта правоотношений выполнять предписания закона и действовать в ходе производства по делу в соответствии с правилами, установленными УПК РФ, и, соответственно, ограничивает их права и свободы.

Конституция Российской Федерации и УПК РФ устанавливают процессуальные гарантии, обеспечивающие законность и обоснованность избрания и применения мер пресечения. Эти меры избираются только должностными лицами уполномоченных органов в ходе производства по уголовному делу; носят процессуальный характер и применяются при наличии к тому достаточных оснований в порядке, установленном в законе.

Наличие законных и обоснованных оснований, а также четкое определение пределов ограничения прав и свобод подозреваемого (обвиняемого) в наибольшей степени способствуют как охране прав и свобод подозреваемого и обвиняемого в уголовном судопроизвод- 
стве, так и назначению уголовного судопроизводства.

В соответствии с п. 13 ст. 5 УПК РФ, избрание меры пресечения - принятие дознавателем, следователем, а также судом решения о мере пресечения в отношении подозреваемого, обвиняемого.

Меры пресечения могут применяться лишь при наличии одного из установленных законом оснований, которые являются общими для всех мер пресечения.

Основаниями для избрания мер пресечения в соответствии с ч. 1 ст. 97 УПК РФ является наличие достаточных оснований полагать, что обвиняемый, подозреваемый:

1. скроется от дознания, предварительного следствия или суда;

2. может продолжать заниматься преступной деятельностью;

3. может угрожать свидетелю, иным участникам уголовного судопроизводства, уничтожить доказательства или иным образом воспрепятствовать производству по уголовному делу.

В соответствии с ч. 2 ст. 97 УПК РФ, основанием для избрания мер пресечения является также необходимость обеспечения исполнения приговора или возможной выдачи лица иностранному государству.

В соответствии с разъяснением Пленума Верховного суда РФ, о том, что лицо может скрыться, могут свидетельствовать тяжесть предъявленного обвинения и возможность назначения наказания в виде лишения свободы на длительный срок либо нарушение лицом ранее избранной в отношении него меры пресечения. О том, что лицо может скрыться за границей, могут свидетельствовать, например, подтвержденные факты продажи имущества на территории РФ, наличия за рубежом источника дохода, финансовых ресурсов, наличия гражданства иностранного государства, отсутствия в Российской Федерации постоянного места жительства, работы, семьи. Вывод о том, что лицо может продолжать заниматься преступной деятельностью, может быть сделан с учетом прежней судимости за умышленное преступление. О том, что обвиняемый может угрожать свидетелю, иным участникам, уничтожить доказательства, могут свидетельствовать наличие угроз с его стороны, иных лиц, предложения указанных лиц выгод материального и нематериального характера с целью фальсификации доказательств по делу, предъявление лицу обвинения в совершении преступления в составе организованной группы или преступного сообщества [2].

Порядок применения мер процессуального принуждения специфичен. Различия обусловлены в первую очередь правами и свободами личности, ограничение которых предполагает избрание конкретной меры. Вывод должностного лица должен быть сделан на основе сбора и изучения всех сведений, имеющих значение для решения вопроса о возможности применения той или иной меры процессуального принуждения.

В соответствии со ст. 99 УПК РФ, при решении вопроса о необходимости избрания меры пресечения в отношении подозреваемого или обвиняемого в совершении преступления и определения ее вида при наличии оснований, должны учитываться также тяжесть преступления, сведения о личности подозреваемого или обвиняемого, его возраст, состояние здоровья, семейное положение, род занятий и другие обстоятельства.

Необходимо учитывать, что основаниями для избрания подозреваемому, обвиняемому меры пресечения являются достаточные данные о том, что он может совершить нежелательные действия, но возможность совершения этих действий носит предположительный, прогностический характер. Эти действия еще не совершены, но могут быть осуществлены. Однако данное предположение должно базироваться на соответствующих основаниях, то есть следователь, дознаватель, а также суд, получив достаточные данные о предполагаемой, прогностической возможности подозреваемого, обвиняемого осуществить поступки, перечисленные в ч. 1 ст. 97 УПК РФ, принимает решение об избрании меры пресечения.

Под достаточностью следует понимать наличие в уголовном деле совокупности сведений, дающих основание для вывода о том, что подозреваемый, обвиняемый, если к нему не будет применена мера пресечения, предположительно осуществит одно или несколько действий, перечисленных в ч. 1 ст. 97 УПК РФ.

Для избрания мер пресечения в качестве оснований необходимо наличие совокупности конкретных сведений о том, что подозреваемый, обвиняемый, предположительно осуществит одно или несколько действий, перечисленных в ч. 1 ст. 97 УПК РФ, при этом одного лишь подозрения или обвинения в совершении преступления недостаточно. Так, Пленум Верховного Суда Российской Федерации отмечал, что «наличие обоснованного подозрения в том, что заключенное под стражу лицо совершило преступление, является необходимым условием для законности ареста... Должны существовать и иные обстоятельства, которые могли бы оправдать изоляцию лица от общества. К таким обстоятельствам, в частности, может относиться возможность того, что подозреваемый, обвиняемый или подсудимый могут продолжить преступную деятельность либо скрыться от предварительного следствия или суда либо сфальсифицировать доказательства по уголовному делу, вступить в сговор со свидетелями. При этом указанные обстоятельства долж- 
ны быть реальными, обоснованными, то есть подтверждаться достоверными сведениями.» [3].

Мера пресечения может быть избрана в отношении обвиняемого, а в исключительных случаях - в отношении подозреваемого. В данном случае обвинение должно быть предъявлено подозреваемому не позднее 10 суток с момента применения меры пресечения, а если подозреваемый был задержан, а затем заключен под стражу - в тот же срок с момента задержания. Если в этот срок обвинение не будет предъявлено, то мера пресечения немедленно отменяется, за исключением случаев, предусмотренных ч. 2 ст. 100 УПК РФ, при этом подозреваемому должно быть предъявлено обвинение в совершении хотя бы одного из преступлений, предусмотренных статьями 205, 205.1, 205.3, 205.4, 205.5, 206, 208, 209, 210, $277,278,279,281,360$ и 361 УК РФ, не позднее 45 суток с момента применения меры пресечения.

В законе не указано, в чем может заключаться исключительность случаев избрания меры пресечения в отношении подозреваемого. Представляется, что исключительность случаев избрания меры пресечения в отношении подозреваемого, когда следователь не располагает достаточными доказательствами, дающими основание для обвинения в совершении преступления, связана с его повышенной общественной опасностью.

При наличии предусмотренных ч. 1 ст. 97 УПК РФ оснований для избрания меры пресечения, общих и специальных условий, при необходимости избрания в качестве меры пресечения запрета определенных действий, домашнего ареста, залога или заключения под стражу, следователь с согласия руководителя следственного органа, а также дознаватель с согласия прокурора возбуждают перед судом соответствующее ходатайство. Рассматриваемое постановление представляет собой уголовно-процессуальную форму, в которой следователь, дознаватель на основе совокупности содержащихся в материалах уголовного дела фактических данных получают основания для применения данной меры пресечения и принимают решение об этом.

В постановлении о возбуждении ходатайства излагаются мотивы и основания, в силу которых возникла необходимость в избрании подозреваемому или обвиняемому меры пресечения. В соответствии со ст. 99 УПК РФ, В указанном постановлении необходимо указать тяжесть преступления, сведения о личности подозреваемого или обвиняемого, его возраст, состояние здоровья, семейное положение, род занятий и другие обстоятельства, учитываемые при избрании данной меры пресечения. К постановлению прилагаются материалы, подтверждающие обоснованность ходатайства. При этом какого-либо конкретного перечня представляемых материалов законом не предусмотрено.
Содержание относительных истин, устанавливаемых при оценке

имеющихся оснований и условий для избрания меры пресечения, отражает существенные стороны, свойства, связи и отношения, касающиеся только возможности совершения подозреваемым, обвиняемым деяния, предусмотренного ч. 1 ст. 97 УПК РФ. Относительные истины, являясь истинами объективными и в силу этого, заключают в себе правильное знание, которое в ходе дальнейшей проверке в судебном заседании может уточняться, пополняться и углубляться.

В результате оценки совокупности имеющихся сведений, дознаватель, следователь на рациональном уровне познания получают выводное знание о том, что обвиняемый (подозреваемый) может: скрыться от предварительного следствия и суда, продолжить заниматься преступной деятельностью или будет уклоняться от исполнения приговора, угрожать свидетелю или иным участникам уголовного судопроизводства, уничтожить доказательства либо иным путем воспрепятствовать производству по уголовному делу. При получении на рациональном уровне познания выводного знания о перечисленных выше фактах и обстоятельствах происходит оценка относительно ограниченной совокупности сведений, относящихся к указанным фактам [4].

Постановление об избрании меры пресечения является правовой формой получения нового, выводного знания, полученного на основании имеющейся в материалах уголовного дела достаточной совокупности фактических данных о том, что подозреваемый, обвиняемый может совершить одно из действий, предусмотренных ч. 1 ст. 97 УПК РФ, с учетом тяжести преступления, сведений о личности подозреваемого или обвиняемого, его возраста, состояния здоровья, семейного положения, рода занятий и других обстоятельств.

В результате использования имеющейся совокупности данных, в анализируемом постановлении делается вывод о необходимости избрания подозреваемому, обвиняемому именно данной меры пресечения и невозможности применения иной, более мягкой, меры пресечения.

При этом следователь не только познает, воспроизводит важнейшие стороны, свойства, связи и отношения исследуемых обстоятельств, не просто следует за содержанием фактических общественных отношений, но и создает предпосылки для реализации новых общественных (уголовно-процессуальных) отношений, формируемых в процессе избрания и применения меры пресечения, направленные на преобразование действительности в целях обеспечения надлежащего поведения подозреваемого (обвиняемого) для решения задач уго- 
ловного судопроизводства.

При принятии судом решения об избрании меры пресечения формируются и реализуются не только новые правовые отношения, но и развиваются или приобретают новые качества уже имеющиеся правоотношения. Так, у обвиняемого, которому избрана мера пресечения в виде домашнего ареста, возникают новые обязанности: находиться в изоляции от общества в жилом помещении, в котором проживает и соблюдать наложенные на него запреты. Соответственно, возникают права и обязанности у контролирующего органа, следователя, дознавателя по осуществлению контроля за соблюдением подозреваемым, обвиняемым меры пресечения и наложенных судом запретов.

Если ходатайство возбуждается в отношении подозреваемого, задержанного в порядке, установленном ст. 91 и 92 УПК РФ, то постановление и указанные материалы должны быть представлены судье не позднее чем за 8 часов до истечения срока задержания.

В соответствии с ч. 4 ст. 108 УПК РФ, постановление о возбуждении ходатайства об избрании в качестве меры пресечения заключения под стражу рассматри- вается единолично судьей районного суда или военного суда соответствующего уровня по месту производства предварительного расследования либо месту задержания подозреваемого в течение 8 часов с момента поступления материалов в суд. В рассмотрении ходатайства обязательно участие подозреваемого или обвиняемого, прокурора, защитника, если последний участвует в уголовном деле. Неявка без уважительных причин сторон, своевременно извещенных о времени судебного заседания, не является препятствием для рассмотрения ходатайства, за исключением случаев неявки обвиняемого. В судебном заседании вправе также участвовать законный представитель несовершеннолетнего подозреваемого или обвиняемого, руководитель следственного органа, следователь, дознаватель.

Рассмотрев ходатайство об избрании меры пресечения, судья выносит постановление об избрании в отношении подозреваемого или обвиняемого меры пресечения либо постановление об отказе в удовлетворении ходатайства. При избрании меры пресечения в постановлении судьи должны быть указаны конкретные, фактические обстоятельства, на основании которых судья принял такое решение.

\section{ЛИТЕРАТУРА}

1. Кондрат И.Н. Обеспечение прав личности в досудебном производстве по уголовным делам: законодательное регулирование и правоприменительная практика: монография. М. Юстицинформ, 2015. 176 с.

2. Постановление пленума Верховного Суда РФ от 19 декабря 2013 г. № 41 «0 практике применения судами законодательства 0 мерах пресечения в виде заключения под стражу, домашнего ареста и залога».

3. П. 14 Постановления Пленума Верховного Суда Российской Федерации от 10 октября 2003 г. № 5 « применении судами общей юрисдикции общепризнанных принципов и норм международного права и международных договоров Российской Федерации».

4. Доля Е.А. Формирование доказательств на основе результатов оперативно-розыскной деятельности: монография. М., Проспект, 2015.376 с.

○ Фирсов Владимир Григорьевич (firsov_vg65@mail.ru). 